\title{
Maple 13 Assisted Problem Based Teaching in Vector Calculus Course
}

\author{
T. Tutut Widiastuti A. ${ }^{*}$, Rahayu Kariadinata ${ }^{2}$ \\ ${ }^{1,2}$ Universitas Islam Negeri Sunan Gunung Djati Bandung \\ *widiastuti@ uinsgd.ac.id
}

Received: November 2020; Accepted: December 2020; Published: January 2021

\begin{abstract}
The purpose of this study was to obtain learning outcomes by looking at the differences between classes learning of Maple 13 application assisted by problem based teaching materials with convensional learning question and answer. The method used in this research is an experimental method with random sampling. The result of thi research are: (a) validation was carried out by competent expert lecturers to assess the feasibility of calculus vector questions to obtain good and very good criteria, so the valid test items were used for research, (b) from the validation results of the test items, 5 questions were used. The research (experiment) of 8 questions was tested, (c) the normality test was carried out on the $N$-gain and the postest score of class A (experiment), namely the class using Maple 13 application learning assisted by problem-based teaching materials and class $B$ (control class) by using learning with lectures and questions and answers, obtained a class A posttest score with a sig. $0.03<0.05$ means that class $A$ (experimental) comes from a population that is not normally distributed, then the next test is the average difference test using the Mann Whitney test, (d) the average difference test between class A (experimental), namely the class using learning Maple 13 application assisted with problem-based teaching materials and class B (control class) using learning with lectures and questions and answers obtained from the Mann Whitney test with Asymp. Sig. (2-tailed $)=0.475>0.05$ means that between class $A$ and class $B$ have different averages but have the same level of achievement or there is no difference for the level of achievement of the average increase.

Keywords: the Maple 13 application assisted by problem-based teaching materials, calculus vector.
\end{abstract}

How to Cite: Widiastuti A., T. T. \& Kariadinata, R. (2021). Maple 13 Assisted Problem Based Teaching in Vector Calculus Course. Journal Of Medives : Journal of Mathematics Education IKIP Veteran Semarang, 5(1), 83-91. 


\section{PENDAHULUAN}

Perkembangan ilmu pengetahuan dan teknologi telah mencapai perkembangan yang sangat luar biasa seiring dengan munculnya komputer. Cara kerja komputer yang praktis, cepat, tepat dan akurat dalam menghasilkan informasi membuat komputer memiliki peranan yang tinggi dalam kehidupan manusia (Aprianto, 2018).

Dalam perkembangan kebutuhan informasi dan pemanfaatan teknologi informasi diharapkan tingkat daya pikir serta kreatifitas pendidik dan peserta didik serta masyarakat dapat berkembang dengan pesat. Dalam buku Intructional Media and Technology for Learning, Heinich menyatakan bahwa keseluruhan sejarah, media dan teknologi telah mempengaruhi pendidikan (Erman, 2003). Sekarang ini komputer telah memberikan pengaruh yang sangat kuat terhadap setting pembelajaran. Komputer menawarkan pembelajaran menjadi lebih baik. Dalam pendidikan, komputer bisa berperan sebagai aplikasi untuk mempermudah belajar, pemanfaatannya meliputi penyajian isi materi pelajaran, latihan atau keduanya. Oleh karena itu, komputer sangat diperlukan dalam belajar pelajaran matematika.

Pelajaran matematika adalah suatu pelajaran yang berhubungan dengan berbagai bidang (Novitasari, 2016), misalnya melatih logika dan nalar, melatih berpikir sistematis, melatih kedisiplinan, dan masih banyak lagi. Dengan makna lain bahwa matematika mempunyai peranan yang sangat esensial untuk ilmu lain, yang utama adalah sains dan teknologi (Siagian, 2016). Sejalan juga dengan pendapat yang dikemukakan oleh Skemp (1971, p.132), "mathematics is also a valuable and generalpurpose technique for satisfying other needs. It is widely known to be an assential tool for science, technology, and commerce; and for entry to many prefessions". Semua itu disebabkan karena matematika menjadi mata pelajaran yang diberikan kepada semua jenjang dimulai dari sekolah dasar untuk membekali peserta didik dengan kemampuan berfikir logis, analitis, sistematis, kritis, dan kreatif, serta kemampuan bekerja sama (Sholihah \& Mahmudi, 2015). Namun masalah tentang sulitnya pelajaran matematika masih sering kali menjadi kendala peserta didik dalam menyerap informasi secara maksimal. Seringkali pendidik harus mencari solusi permasalahan tersebut, salah satunya membuat strategi penyampaian materi dan pemilihan media yang tepat untuk membantu peserta didik dalam mempermudah memahami konsep matematika.

Strategi penyampaian materi yang terencana memegang peranan penting dalam proses pembelajaran (Fatimah \& Kartikasari, 2018). Dalam hal ini pendidik membuat strategi penyampaian materi dengan penggunaan media pembelajaran yang mudah dan menarik. Penerapan media pembelajaran berbasis teknologi informasi adalah penggunaan perangkat keras (hardware) teknologi informasi seperti komputer, laptop, infocus yang didukung dengan pemanfaatan perangkat lunak (software) seperti software untuk melakukan presentasi, menampilkan gambar bergerak (video) dan suara (audio) sebagai alat bantu bagi pendidik dalam menyampaikan materi 
pembelajaran (Adam, 2015). Media ini merupakan salah satu solusi untuk mengatasi abstraknya materi matematika dalam pembelajaran. Menurut (Erman, 2003) jenis-jenis media ada beberapa macam, diantaranya adalah media komputer melalui software yang ada didalamnya. Media komputer dapat membantu dalam proses belajar mengajar, sehingga keabstrakan materi dapat dikurangi. Tujuannya adalah untuk menarik minat belajar peserta didik serta meningkatkan pemahaman kearah yang lebih komplek.

Media komputer dewasa ini telah memegang peran penting dalam proses pembelajaran. Media komputer dapat memperlancar pemahaman peserta didik dan memperkuat ingatannya. Komputer dapat pula menumbuhkan minat peserta didik dan dapat memberikan hubungan antara isi materi pelajaran dengan dunia nyata. Agar pembelajaran lebih efektif, komputer sebaiknya ditempatkan pada konteks yang bermakna dan peserta didik harus berinteraksi dengannya untuk meyakinkan terjadinya proses informasi (Widiastuti \& Hidayanto, 2018).

Salah satu program digital komputer adalah pemanfaatan program bantuan software Maple sebagai alat pembelajaran. Maple merupakan suatu software yang kemampuannya tidak hanya sebagai alat hitung (tool for computing) seperti halnya kalkulator tangan biasa, namun lebih jauh dari itu Maple sangat tepat digunakan sebagai alat pembelajaran matematika khususnya kalkulus (Qodariyah \& Ismai, 2014). Menurut (Widiastuti \& Hidayanto, 2018) program Maple adalah salah satu dari beberapa software (aplikasi/ perangkat lunak) komputer yang digunakan untuk menyelesaikan berbagai persoalan matematika. Maple berjalan pada sistem operasi keluarga Windows dan cukup mudah untuk digunakan. Dengan menggunakan program ini, banyak solusi yang ditemukan dan dapat menyelesaikan persoalan matematika, baik berupa masalah aritmatika, aljabar, trigonometri, maupun kalkulus.

Maple ideal untuk merumuskan, menyelesaikan, dan memeriksa model matematika. Antarmuka (interface) grafiknya merupakan fasilitas yang paling diharapkan dalam software aplikasi modern. Grafik dapat memuat banyak informasi. Para ilmuwan berpendapat bahwa membuat grafik merupakan salah satu cara untuk mencari kaitan antara satu variabel dengan variabel yang lain. Grafik memungkinkan para ilmuwan untuk menggunakan fasilitas-fasilitas yang sudah diakui dengan pola visual yang sangat kuat untuk melihat kecenderungan-kecenderungan dan titik-titik perbedaan yang sulit dideteksi, dan dengan itu kemampuan bekerja dengan grafik merupakan kemampuan dasar ilmuwan (Junaidi, 2016).

Maple memiliki beberapa keunggulan di antaranya: 1) Maple merupakan program yang interaktif yang memungkinkan komputasi matematika dengan melibatkan simbol-simbol, 2) Maple memuat paket-paket matematika yang siap pakai dalam jumlah yang cukup banyak sehingga Maple unggul dalam pengerjaan matematika, dan 3) Maple dapat digunakan sebagai bahasa pemrograman sehingga pengguna dapat 
mengimplementasikan algoritma matematika baru (Puspadewi \& Atmaja, 2015). Sedangkan menurut (Afgani, 2016), salah satu kekurangan dari program Maple adalah cukup sulit menjelaskan materi geometri, karena untuk menampilkan bangun geometri atau memanipulasinya harus menginput sintaks yang tidak sederhana, tidak seperti Cabri, Geogebra, atau sejenisnya yang hanya menggunakan Tools yang tersedia. Oleh karena itu pada mata kuliah kalkulus vektor ini selain pembelajaran menggunakan aplikasi Maple, juga menggunakan bahan ajar berbasis masalah untuk mempermudah penerapan Maple dalam menyelesaikan masalah Kalkulus Vektor.

Bahan ajar merupakan salah satu faktor penting dalam keefektifan sebuah pembelajaran terlebih di tingkat Perguruan Tinggi. Kurangnya bahan ajar tentunya dapat mempengaruhi kualitas pembelajaran atau perkuliahan (Arsanti, 2018). Bahan ajar matematika adalah seperangkat materi matematika sekolah yang disusun secara matematis, baik tertulis maupun tidak tertulis, sedemikian sehingga tercipta lingkungan atau suasana yang memungkinkan bagi peserta didik untuk belajar matematika (Ibrahim, 2011). Terdapat sejumlah alasan dan pendapat mengapa bahan ajar matematika penting. Beberapa di antaranya adalah karena bahan ajar matematika harus sesuai tujuan pembelajaran matematika pada kurikulum, karakteristik sasaran, dan tuntutan pemecahan masalah belajar.

Dengan bahan ajar, maka peserta didik dapat mempelajari suatu kompetensi secara runtut dan sistematis bahkan secara mandiri. Bahan ajar berbasis masalah disusun menjadi tiga bagian yaitu pendahuluan, kegiatan inti, dan penutup. Pendahuluan terdiri dari deskripsi bahan ajar, petunjuk penggunaan, tujuan pembelajaran, dan kompetensi yang akan dicapai peserta didik. Bagian kegiatan inti dibagi menjadi beberapa bagian sesuai dengan subbab dalam mata kuliah kalkulus vektor. Kegiatan dimulai dengan pemberian masalah yang berkaitan dengan materi. Permasalahan tersebut dapat membantu mahasiswa dalam mengkonstruksi konsep yang diajarkan. Bagian penutup berupa latihan soal untuk lebih memperdalam konsep dan menemukan banyak variasi masalah dalam mata kuliah kalkulus vektor.

\section{METODE PENELITIAN}

Metode yang digunakan dalam penelitian ini adalah metode eksperimen dengan pengambilan sampel secara acak. Dalam penelitian ini diperlukan dua kelompok, pertama adalah kelompok eksperimen yang diberi perlakuan berupa pembelajaran dengan aplikasi Maple 13 berbantuan bahan ajar berbasis masalah dan yang kedua kelompok kontrol, yang diberi pembelajaran biasa yaitu pembelajaran dengan ceramah dan tanya jawab yang sehari-hari dilakukan pada mata kuliah kalkulus vektor. Sebelum dan sesudah perlakuan kedua kelompok diberi tes. Desain penelitiannya adalah sebagai berikut.

\begin{tabular}{c|c|c|c|c}
\hline $\mathbf{A}$ & $:$ & $\mathbf{O}$ & $\mathbf{X}$ & $\mathbf{O}$ \\
\hline $\mathbf{A}$ & $:$ & $\mathbf{O}$ & & $\mathbf{O}$ \\
\hline
\end{tabular}


Keterangan:

A : Pengambilan sampel secara acak kelas

$\mathrm{O}$ : Tes awal dan tes akhir

$\mathrm{X}$ : Pemberian perlakuan berupa pembelajaran dengan aplikasi Maple 13 berbantuan bahan ajar berbasis masalah.

Populasi dalam penelitian adalah seluruh mahasiswa prodi Pendidikan Matematika semester IV kelas A, B, dan C. Sugiyono (2011: 81) menyatakan bahwa sampel adalah bagian dari jumlah dan karakteristik yang dimiliki oleh populasi tersebut. Berdasarkan pengertian sampel, dapat diketahui bahwa sampel merupakan perwakilan dari populasi yang hasil penelitiannya bisa mewakili keseluruhan gejala yang diamati. Cara menentukan sampel dalam penelitian ini dengan Cluster Random Sampling.

Instrumen yang digunakan pada penelitian ini adalah dua perangkat tes berbentuk soal uraian, yaitu tes awal dan tes akhir yang semuanya digunakan untuk mengukur kemampuan mahasiswa dalam pembelajaran kalkulus vektor dengan aplikasi Maple 13 berbantuan bahan ajar berbasis masalah. Prosedur penelitian terdiri dari dari 1) Tahap Persiapan, 2) Tahap Pelaksanaan, dan 3) Tahap Evaluasi. Pada tahap persiapan, sebelum penelitian ini dilaksanakan terlebih dahulu diadakan persiapanpersiapan yang dipandang perlu, antara lain: melakukan studi kepustakaan mengenai pembelajaran dengan aplikasi Maple 13 dan pembelajaran dengan bahan ajar berbasis masalah, membuat rancangan pembelajaran. Setelah persiapan dianggap cukup, dilanjutkan pemilihan sampel dan dilanjutkan dengan penyusunan instrumen penelitian, melakukan uji coba coba instrumen serta merevisi instrumen tersebut agar dapat digunakan dalam penelitian. Selanjutnya langkah pelaksanaan, dalam langkah ini, dimulai dengan memberi tes awal untuk mengukur kehomogenan kemampuan awal mahasiswa pada awal penelitian. Sebelum pelaksanaan pembelajaran dengan aplikasi Maple 13 berbantuan bahan ajar berbasis masalah di kelas eksperimen, maka diadakan sosialisasi dengan memberikan penjelasan mengenai aturan-aturan yang diterapkan dalam pembelajaran menggunakan aplikasi Maple 13 berbantuan bahan ajar berbasis masalah. Selanjutnya diadakan latihan atau menguji coba pembelajaran tersebut dan sekaligus digunakan untuk pembentukan kelompok. Dalam penelitian ini penulis berperan sebagai dosen pengajar yang memberikan materi dan sekaligus tugas kepada mahasiswa, dengan pertimbangan untuk mengurangi bias karena perbedaan perlakuan pada masing-masing kelas. Pelaksanaan pembelajaran dilaksanakan pada bulan Juni-Agustus. Sebagai langkah terakhir, yaitu pemberian tes akhir kepada kedua kelompok, kemudian dihitung $\mathrm{N}$-gain peningkatannya.

\section{HASIL DAN PEMBAHASAN}

Hasil penelitian ini membahas hasil validasi ahli, hasil validasi uji coba butir soal, hasil uji normalitas, dan uji perbedaan antara kelas yang menggunakan pembelajaran dengan aplikasi Maple 13 berbantuan bahan ajar berbasis masalah dengan kelas kontrol. 
Tabel.1 Rekap Hasil Uji Coba Butir Soal

\begin{tabular}{ccccccc}
\hline No. Soal & rhitung & Validitas & Tingkat Kesukaran & $\mathbf{t}_{\text {hitung }}$ & Daya Pembeda & Keterangan \\
\hline 1 & 0,6037 & Valid & Sulit & 2,5346 & Signifikan & Dipakai \\
2 & 0,6106 & Valid & Mudah & 4,1043 & Signifikan & Dipakai \\
3 & 0,1502 & Tidak Valid & Mudah & 1,0001 & Tidak Signifikan & Tidak Dipakai \\
4 & 0,5049 & Valid & Sedang & 3,0911 & Signifikan & Dipakai \\
5 & 0,3904 & Tidak Valid & Sedang & 1,5009 & Tidak Signifikan & Tidak Dipakai \\
6 & 0,8610 & Valid & Sulit & 17,3545 & Signifikan & Dipakai \\
7 & 0,5134 & Valid & Sedang & 3,1620 & Signifikan & Dipakai \\
8 & 0,3402 & Tidak Valid & Sulit & 1,3334 & Tidak Signifikan & Tidak Dipakai \\
\hline
\end{tabular}

\section{Hasil Validasi Ahli}

Salah satu kriteria utama untuk menentukan dipakai tidaknya suatu soal tes adalah hasil validasi oleh ahli. Dalam hal ini dosen yang ahli dalam bidang ini adalah Bapak Zaenal Saeful, M.Pd. Validasi ini dilakukan untuk melihat validitas isi dari draft 1 yang telah disusun dan disesuaikan dengan pembelajaran dengan aplikasi Maple 13 berbantuan bahan ajar berbasis masalah pada mata kuliah kalkulus vektor. Validasi dilakukan dosen ahli yang berkompeten untuk menilai kelayakan soal kalkulus vektor mendapatkan hasil dengan kriteria baik dan sangat baik maka soal tes dapat digunakan untuk penelitian dan valid.

\section{Hasil Validasi Uji Coba Butir Soal}

Setelah proses validasi isi dan construct oleh para ahli terhadap tes awal dan akhir, maka uji coba butir soal tes dilakukan untuk mendapatkan validitas, reliabilitas, tingkat kesukaran butir soal, dan daya pembeda. Uji coba dilakukan di kelas C dengan mahasiswa sebanyak 37 mahasiswa. Rekap analisis hasil uji coba butir soal dapat dilihat pada Tabel 1 .

Dari hasil validasi uji coba butir soal didapat 5 soal yang dipakai penelitian (eksperimen) dari 8 soal yang dilakukan uji coba.
Tabel 2. Hasil Uji Normalitas Posttest Tests of Normality

\begin{tabular}{lrlrrr}
\hline \multicolumn{5}{c}{ Tests of Normality } \\
\hline \multicolumn{5}{c}{ Kolmogorov-Smirnov } & \multicolumn{1}{c}{ Shapiro-Wilk } \\
\hline Statistic & df & Sig. & Statistic df & Sig. \\
\hline postesA & .148 & 37 & .041 & .934 & 37.030 \\
postesB & .142 & 37 & .059 & .958 & 37.171 \\
\hline a. Lilliefors Significance Correction &
\end{tabular}

\section{Hasil Uji Normalitas}

Uji normalitas dalam penelitian ini dilakukan pada dua kategori sampel, yang pertama uji normalitas pada postest (hasil tes akhir) pada kelas A dan kelas B dan yang kedua uji normalitas $\mathrm{N}$-gain. Untuk menentukan $\mathrm{N}$-gain digunakan rumus $N_{\text {gain }}=\frac{\text { skor posttest-skor pretest }}{100-\text { skor pretest }}$.

Tabel 2 memperlihatkan hasil dari masing-masing uji normalitasnya yag diuji menggunakana SPSS 16.0. Dari hasil pengujian Normalitas Postest Kelas A (eksperimen), yaitu kelas dengan menggunakan pembelajaran aplikasi Maple 13 berbantuan bahan ajar berbasis masalah, dan kelas B (kelas kontrol) ,yaitu kelas dengan menggunakan pembelajaran dengan ceramah dan tanya jawab, didapat skor posttest kelas A nilai sig. $0.03<0.05$ artinya $\mathrm{H}_{0}$ ditolak, berarti data tidak normal. Karena ada salah satu data yang tidak normal maka pengujian perbedaan rata-rata dilanjutkan dengan uji non parametrik "Uji mann whitney". 


\section{Hasil Uji Normalitas N-Gain}

Begitu juga dilihat dari hasil pengujian Normalitas N-gain Kelas A (eksperimen) yaitu kelas dengan menggunakan pembelajaran aplikasi Maple 13 berbantuan bahan ajar berbasis masalah dan kelas B (kelas kontrol) dengan menggunakan pembelajaran dengan ceramah dan tanya jawab didapat skor $\mathrm{N}$-gain kelas A nilai sig. $0.015<$ 0.05 artinya $\mathrm{H}_{0}$ ditolak, berarti data tidak normal.

Tabel 3. Hasil Uji Normalitas N-Gain

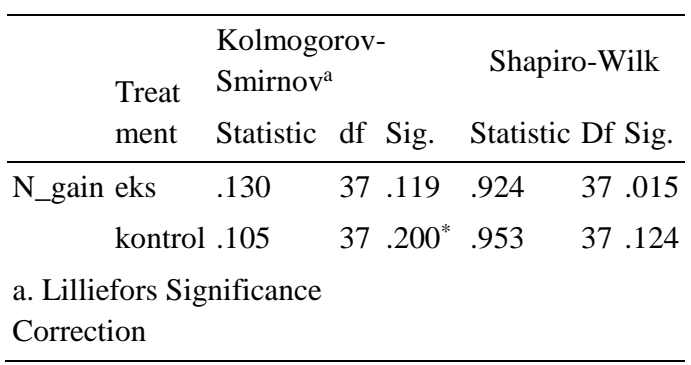

\section{Hasil Uji Perbedaan Rata-Rata Posttest}

Dilihat dari hasil pengujian perbeda-an rata-rata hasil postest dengan uji mann whitney didapat Asymp. Sig. (2-tailed) $=0.002<0.05$ artinya terdapat perbedaan rata-rata antara postest kelas A (eksperimen) yaitu kelas dengan meng-gunakan pembelajaran aplikasi Maple 13 berbantuan bahan ajar berbasis masalah dan kelas B (kelas kontrol) dengan menggunakan pembelajaran dengan ceramah dan tanya jawab.

\begin{tabular}{llccc}
\multicolumn{4}{c}{ Tabel 4. Ranks } \\
\hline & & & Mean & Sum of \\
& treatment & $\mathrm{N}$ & Rank & Ranks \\
\hline skor & eksperimen & 37 & 45.20 & 1672.50 \\
& kontrol & 37 & 29.80 & 1102.50 \\
& Total & 74 & & \\
\hline
\end{tabular}

Tabel 5. Test Statistics ${ }^{\mathrm{a}}$

\begin{tabular}{lr}
\hline & \multicolumn{1}{c}{ skor } \\
\hline Mann-Whitney U & 399.500 \\
Wilcoxon W & $1.102 \mathrm{E} 3$ \\
Z & -3.085 \\
Asymp. Sig. (2-tailed) & .002 \\
\hline \multicolumn{2}{l}{ a. Grouping Variable: treatment }
\end{tabular}

\section{Uji Perbedaan Peningkatan}

Dilihat dari hasil pengujian perbedaan rata-rata hasil N-Gain dengan uji mann whitney didapat Asymp. Sig. (2tailed) $=0.475>0.05$ artinya tidak terdapat peningkatan antara kelas A (eksperimen) yaitu kelas dengan menggunakan pembelajaran aplikasi Maple 13 berbantuan bahan ajar berbasis masalah dan kelas B (kelas kontrol) dengan menggunakan pembelajaran dengan ceramah dan tanya jawab atau dengan kata lain dapat disimpulkan bahwa antara kelas A dan kelas B mempunyai rata-rata yang berbeda tetapi mempunyai tingkat pencapaian yang sama atau tidak terdapat perbedaan untuk tingkat pencapaian peningkatan rata-rata.

Tabel 6. Ranks

\begin{tabular}{|c|c|c|c|}
\hline treatment & $\mathrm{N}$ & $\begin{array}{l}\text { Mean } \\
\text { Rank }\end{array}$ & $\begin{array}{l}\text { Sum of } \\
\text { Ranks }\end{array}$ \\
\hline ngain eksperimen & 37 & 39.28 & 1453.50 \\
\hline kontrol & 37 & 35.72 & 1321.50 \\
\hline Total & 74 & & \\
\hline
\end{tabular}

Tabel 7. Test Statistics ${ }^{a}$

\begin{tabular}{lr}
\hline & \multicolumn{1}{c}{ ngain } \\
\hline Mann-Whitney U & 618.500 \\
Wilcoxon W & $1.322 \mathrm{E} 3$ \\
Z & -.714 \\
Asymp. Sig. (2-tailed) & .475 \\
\hline \multicolumn{2}{l}{ a. Grouping Variable: trestment }
\end{tabular}




\section{DAFTAR PUSTAKA}

Adam, S. (2015). Pemanfaatan Media Pembelajaran Berbasis Teknologi Informasi Bagi Siswa Kelas X Sma Ananda Batam. Computer Based Information System Journal, 3(2), Article 2. http://113.212.163.133/index.php/ cbis/article/view/400

Afgani, M. W. (2016). Pemecahan Masalah dan Menanam Pemahaman Konsep Matematika melalui Software Maple. Jurnal Pendidikan Matematika RAFA, 2(1), 85-103.

Aprianto, B. (2018). Sistem Informasi Laporan Data Pertambangan pada Dinas Pertambangan dan Energi Tembilahan Berbasis Web. SISTEMASI: Jurnal Sistem Informasi, 2(2), 58-60. https://doi.org/10.32520/stmsi.v2i 2.168

Arsanti, M. (2018). Pengembangan Bahan Ajar Mata Kuliah Penulisan Kreatif Bermuatan Nilai-Nilai Pendidikan Karakter Religius Bagi Mahasiswa Prodi PBSI, FKIP, UNISSULA. KREDO : Jurnal Ilmiah Bahasa dan Sastra, 1(2), 69-88.

https://doi.org/10.24176/kredo.v1i 2.2107

Erman, S. (2003). . Strategi Pembelajaran Matematika Kontemporer. Universitas Pendidikan Indonesia.

Fatimah, F., \& Kartikasari, R. D. (2018). Strategi Belajar dan Pembelajaran dalam Meningkatkan Keterampilan Bahasa. Pena Literasi, 1(2), 108-113. https://doi.org/10.24853/pl.1.2.10 8-113
Ibrahim. (2011). Pengembangan bahan ajar matematika sekolah berbasis masalah terbuka untuk memfasilitasi pencapaian kemampuan berpikir kritis dan kreatif matematis siswa. Prosiding Seminar Nasional Matematika dan Pendidikan Matematika, 122-132.

Junaidi, J. (2016). Penggunaan Software Maple dalam Pembelajaran Matematika pada Materi Integral. Visipena Journal, 7(2), Article 2. https://visipena.stkipgetsempena.a c.id/?journal=home\&page $=$ article \&op=view\&path $\% 5 \mathrm{~B} \% 5 \mathrm{D}=144$

Novitasari, D. (2016). Pengaruh Penggunaan Multimedia Interaktif terhadap Kemampuan Pemahaman Konsep Matematis Siswa. FIBONACCI: Jurnal Pendidikan Matematika dan Matematika, 2(2), 8-18. https://doi.org/10.24853/fbc.2.2.818

Puspadewi, K. R., \& Atmaja, I. M. D. (2015). Pemanfaatan Program Aplikasi Maple Sebagai Upaya Meningkatkan Motivasi dan Prestasi Belajar Kalkulus I Mahasiswa Program Studi Pendidikan Matematika Universitas Mahasaraswati Denpasar Tahun Ajaran 2014/2015. Jurnal Bakti Saraswati (JBS), 4(01), Article 01. http://jurnal.unmas.ac.id/index.ph $\mathrm{p} /$ Bakti/article/view/75

Qodariyah, E., \& Ismai, A. D. (2014). Pembelajaran Kalkulus Dengan Bantuan Maple. Jurnal Humanity, 8(1), Article 1. http://ejournal.umm.ac.id/index.p hp/humanity/article/view/1983

Sholihah, D. A., \& Mahmudi, A. (2015). Keefektifan experiential learning pembelajaran matematika MTs 
materi bangun ruang sisi datar. Jurnal Riset Pendidikan Matematika, 2(2), 175-185. https://doi.org/10.21831/jrpm.v2i2 .7332

Siagian, M. D. (2016). Kemampuan Koneksi Matematik daalam Pembelajaran Matematika. MES: Journal of Mathematics Education and Science, 2(1), Article 1. https://doi.org/10.30743/mes.v2i1. 117

Skemp, R. R. (1971). The psycholology of learning mathematics. Baltimore, MD: Richard Clay (The Causer Press) Ltd.

Sugiyono. 2011. Metode Penelitian Kuantitatif Kualitatif dan $R \& D$. Bandung: Alfabeta

Suherman, E. 2003. Strategi Pembelajaran Matematika Kontemporer. Jakarta: Universitas Pendidikan Indonesia

Widiastuti, T. T., \& Hidayanto, M. N. (2018). Pembelajaran Kalkulus Sma Dengan Menggunakan Software Maple 13. Al-Khidmat, l(2), 89-96. https://doi.org/10.15575/jak.v1i2. 3339 